\title{
The Uncanny in Writing the Picture (2010) by John Fuller and David Hurn
}

De l'inquiétante étrangeté dans Writing the Picture (2010) de John Fuller et David Hurn

\section{Aurélien Saby}

\section{(2) OpenEdition}

\section{Journals}

Electronic version

URL: http://journals.openedition.org/etudesecossaises/1306

ISSN: 1969-6337

\section{Publisher}

UGA Éditions/Université Grenoble Alpes

Printed version

ISBN: 978-2-37747-001-3

ISSN: 1240-1439

\section{Electronic reference}

Aurélien Saby, «The Uncanny in Writing the Picture (2010) by John Fuller and David Hurn », Études écossaises [Online], 19 | 2017, Online since 01 April 2017, connection on 08 September 2020. URL: http://journals.openedition.org/etudesecossaises/1306

\footnotetext{
This text was automatically generated on 8 September 2020

() Études écossaises
} 


\title{
The Uncanny in Writing the Picture (2010) by John Fuller and David
}

\section{Hurn}

\author{
De l'inquiétante étrangeté dans Writing the Picture (2010) de John Fuller et \\ David Hurn
}

Aurélien Saby

So many photographs produce a sense of strangeness in the minds of the viewers that it

almost rises to the level of a characteristic common to fine photographs. Certainly, in so many pictures, it is an important, even crucial, element in their success. (Hurn \& Jay, 2000, p. 53)

1 David Hurn (b. 1934) has always been drawn to unusual landscapes, especially unexpected scenes captured in the Welsh daily life of his fellow citizens, whether in his village, Tintern, in the streets of Cardiff, or at a seaside resort. And so has John Fuller (b. 1937), a keen observer of uncanny littorals:

So we stare down the littoral,

Just as we calculate the night,

For stalactite or meteorite,

Behaviour of stone or light

Departing from the ususal. ("Star-Gazing", in Fuller, 2012, p. 90)

2 From the late 1980s onwards, the two artists started a collaboration which gave rise to the publication of a book entitled Writing the Picture ${ }^{2}$ (2010) where Hurn's photography sparks a poetry in which Fuller draws out meaning and launches into thoughtprovoking verse. Here is how they relate the origin of their Welsh adventure in the introduction to their common work:

DH: We should explain how the book came about.

JF: Yes, we met in 1989, didn't we? 
DH: I was living in Wales then, having returned from London in 1973. My purpose was to discover through photography what 'Welsh Culture' means. I was attempting the gathering of evidence for history. I was asked by Colin Jacobson, picture editor of the Independent, if he could use some of the pictures I was working on in Wales. [...] I had just read and enormously enjoyed your novel Flying to Nowhere, so I agreed to supply Welsh pictures on condition that the magazine could get you to do the text. (WP, pp. 8-9)

3 My contention in this article is that the uncanny is one of the points of confluence between Hurn's and Fuller's aesthetics. Not only shall we explore the strangeness, oddness or weirdness characterizing the photos and how they are harnessed by the poet, but we shall also examine Freud's "unheimlich" as a way to better grasp the complex interactions between the pictures and the poems. And for this purpose, Julia Kristeva's concise definition of Freud's concept could serve as a starting point for our study:

Freud wanted to demonstrate at the outset, on the basis of a semantic study of the German adjective heimlich and its antonym unheimlich that a negative meaning close to that of the antonym is already tied to the positive term heimlich, "friendly comfortable," which would also signify "concealed, kept from sight," "deceitful and malicious," "behind someone's back." Thus, in the very word heimlich, the familiar and intimate are reversed into their opposites, brought together with the contrary meaning of "uncanny strangeness" harbored in unheimlich. Such an immanence of the strange within the familiar is considered as an etymological proof of the psychoanalytic hypothesis according to which the uncanny is that class of the frightening which leads back to what is known of old and long familiar, which, as far as Freud was concerned, was confirmed by Schelling who said that "everything is unheimlich that ought to have remained secret but has come to light". (1991, pp. 182-3)

4 When captured by Hurn, Welsh ordinary life often becomes extra-ordinary, sometimes on the brink of the sur-real or super-natural, thus disarming the viewers whose stable bearings are shattered. According to Hurn, "the best photography not only reproduces the visible but also makes visible the unseen" (WP, p. 8). This is particularly true of his own work, further delved into by a poet already prone to throwing light on the invisible. Writing the Picture is peopled with uncanny revenants-half human half automaton, or living dead-caught in unsuspected plots involving doubles of themselves, and ourselves, while undeniably testifying to the photographer's and poet's skills in renewing the genius of Welsh art.

\section{“Departing from the usual"}

\section{Blurred time and space}

Spatiotemporal bearings are more often than not bewildering in Writing the Picture insofar as quite a few snapshots are both deep-rooted in Welsh history and atemporal. For example, some photos are very easy to date given their reportage-like quality, as is illustrated by the beach scene in summer time featuring fathers and their children enjoying the sea at low tide (WP, p. 16). ${ }^{3}$ We may not guess that it was taken in the resort of Barry Island, but the striped swimming suits, together with the bell-bottom trousers of the character on the left as well as the men's haircuts reflect the fashion of the early 1970s, in accordance with the notes on the Magnum Photos website: "the picture is during the 'miners'week,' the holiday period of the miners of South Wales. 
[...] Due to the closing of the pits, this cultural happening no longer takes place." Yet, the generic present of Fuller's lines endows this scene with a kind of unexpected universal timelessness:

From Colwyn to Barry,

From Dee to the Wye,

Water's a carpet

To let me lie. (WP, p. 16)

By adopting a young child's viewpoint, the poet takes us out of history, back to timeless happy memories of holidays in childhood-back to our own first encounter with the sea. Furthermore, these lines echo his own poetry for children, notably "Waves" in You're Having Me On where the speaker makes one with the sea:

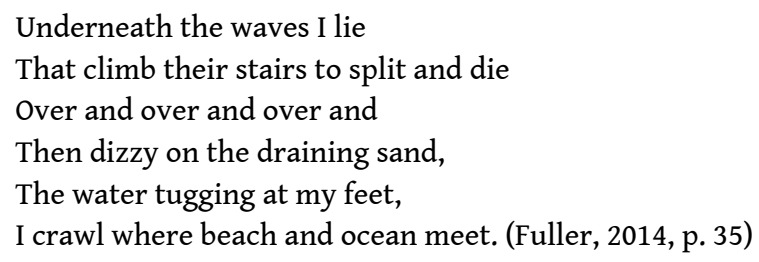

7 But then comes a twist in the poem which suddenly interrelates pleasure and suffering in the rhyme, before making a frightful statement on the devastating power of time, thus wrecking the wonder of the nursery rhyme-like incipit:

The sea taught us our lonely pleasures.

The sea that bore us taught us to suffer.

[...]

Sixty years into our oblivion we are locked into pity.

All in all, one may conclude that in this case the poem adds an uncanny dimension to a picture that was originally devoid of it, thereby highlighting its artistry beyond its documentary aspect.

9 Conversely, other pictures are almost impossible to date, as is exemplified by the obscure forest taken by Hurn in winter (WP, p. 41). The dead branches, coupled with subtle light and shadow nuances, imbue the undergrowth with an eerie, almost supernatural mood, whereas there are no special effects in the silver print. Because the references are only mentioned at the very end of Writing the Picture (in the "List of Images", p. 112), it is almost impossible to guess that this photo actually represents Tintern Forest in 1976. Moreover, the poem does give it a temporal frame; but it sets it in the Middle Ages, somehow bringing us back to ageless Arthurian legends:

Our course, over across river

North to Tintern in that night-run

Went, towards winter woods,

The climb behind, the calm beyond. (WP, p. 40)

In order to illustrate this picture, Fuller chose the complex Old Welsh form of the cynghanedd, ${ }^{4}$ which has manifold contrasted effects. First, it contributes to strengthening the mysteriousness of Hurn's picture as the plot involves some ungraspable uncanny revenants in defeat after a battle entirely made up by Fuller, as though the text had been translated-or exhumed-from an Old English tale:

Thorns made thin smoke.

And so we all sat, uneasily lost,

Fellowship's false hopes,

Betrayal by trial

That failed the field. (WP, p. 40) 
11 Second, Fuller's cynghanedd also enhances the Welshness of Hurn's art (which is far from obvious in this picture), while opening up the horizons of the photo in an anachronistic blur shattering all stable spatiotemporal bearings.

\section{"Here the sun has been excluded"}

What is more, in a few other photos, Hurn's perfect mastery of light makes it difficult to know whether they were taken during the day or at night. For instance, Llanwern steel works (WP, pp. 38-9), which was obviously photographed during the working hours of the day, is plunged in utter darkness. And Fuller's poem spotlights the dramatic quality of the scene in a description erasing the boundaries between drama and real life, natural and supernatural laws: "Here is the locked night of the actor's agony". The adverb "here" is caught in an anaphoric system aiming at isolating two entirely distinct worlds: the steel works, here, and the viewers' world, there:

Here the sun has been excluded for his revolutionary idea

That life might be as simple as growing and dying,

Treading the sky in a lifetime of daytimes,

Raising the sweet textures of hills to the unpausing teeth of sheep.

Here the sky itself has been reprimanded for its idle behavior

[...]. (WP, p. 38)

Some alien forces appear all the more threatening as they are ungraspable and only alluded to in passive forms, without any further explanation: "the sun has been excluded"; "the sky itself has been reprimanded". Helpless, we are presented with a gloomy parallel world which is nonetheless not entirely fictional since it was inspired by Shotton steel works during its last day before closing in 1977. The sense of doom is reinforced by the dreadful dehumanizing process at work in the conclusive lines:

Here is the purposive concentration of the worm-in-the-brain

Who conceived the hard straight lines that rule the world of men

And who poured out men's hearts in a thousand boiling suns.

Now they are dispossessed and

The crucible is cursed. (WP, p. 38)

Fuller's hypallages contain a variety of implications. On the one hand, they allow the satirist to denounce the mining authorities' mismanagement and weaknesses. Besides, they underline their callousness ("the hard straight lines that rule the world of men") as well as their powerlessness faced with the almighty evil force of the "worm-in[their]-brain". On the other hand, they pay tribute to the workers by associating their hearts to "a thousand boiling suns" instilling new beats and life in this dark world, thus reigniting beauty at the heart of chaos. And of course, both the photographer and the poet remind us that some miners live in the shadow of our world and in the shadow of themselves: "they are dispossessed". Those doomed souls nevertheless also enable us to follow "the hard straight lines that rule the world of men", that is to say our own world, with its steel bridges and railways and armament...

Likewise, in another picture featuring a swan gone astray in a flooded field (WP, p. 37), the ambiguity between night and day creates an uncanny atmosphere harboured by the poet who adds a moon to the scenery in the last stanza:

The moon shines coldly on unusual waters

As though the night called for a looking glass.

Sins of mothers fall upon the daughters. 
Parting's an ache that had to come to pass.

Whose fault the flood? Whose loss the grass?

Forget-me-late, forget-me-never,

Until the street becomes a river. (WP, p. 36)

The speaker is a young woman who falls in love and is soon abandoned by her loverboy. Wondering to what extent the "moon" here associated to "unusual waters" might be related to menstrual cycles and the fertility of art that would counterbalance the young woman's unhappy love affair, I asked John Fuller himself about the symbolism of this stanza, and I am grateful to him for his clarifying answer dated 26 April 2016:

I wasn't thinking of menstruation at all, but merely the cycle of succumbing to the charm of feckless and betraying men (and of course bearing children as a result: the daughter repeats the process). Not intended to be cynical, merely a very traditional sort of lyrical complaint about the excitement of love and the inevitable parting.

The very last line of this poem ("Until the street becomes a river") is quite ambiguous and inauspicious: an uncanny harbinger of death? Will the river flooding the street wash the forsaken lover's tears away? Or will the flood spread to the entire city? Should it be interpreted as a reminder that everything fades in time, including love, as in those famous lines by W. H. Auden whose shadow hovers over Fuller's poem? ${ }^{5}$

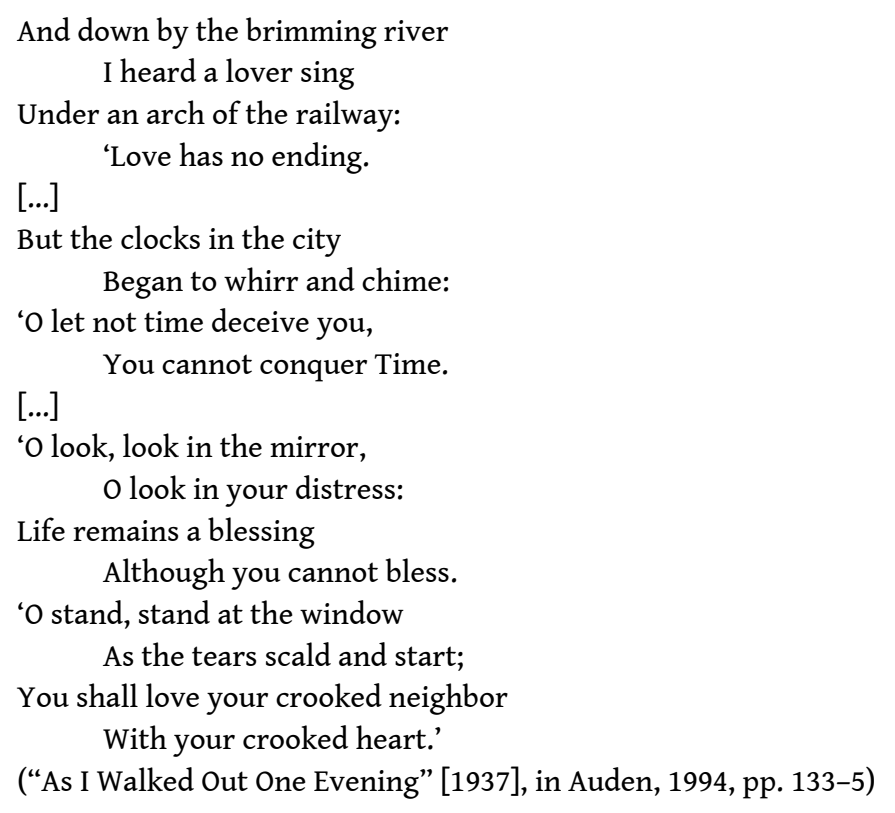

\section{"Threshold-The Disturbing Image"}

Like the drifting swan whose beauty proceeds from the debris of a polluted flooded field, other scenes from Writing the Picture verge on surrealism. As Bill Jay notices, "in these cases the effort to capture the real has slipped into the surreal. Photography is particularly and peculiarly prone to producing these slippages in which a prosaic document of something, extracted from its original context, acts as a trigger to unexpected and even disconnected emotions" (Hurn \& Jay, 2000, p. 53). For example, the sense of humour in the photo portraying two sheep finding shelter in a shed (WP, p. 13)-an unintended parody of 18th century portrait painting, with a beautiful tree on the left and a couple in the foreground ${ }^{6}$-stems from the unsuspected anthropomorphism of such a sight on the side of a Welsh road. This dimension is 
explored further by the poet who visualizes the sheep in a lift, not unlike miners, about to descend to some unknown territory:

While over Mynedd Eppynt drift

Exhausted particles of rain,

And sheep are waiting in a lift

As though they might descend again. (WP, p. 12)

The uncanniness underlying such scenes originates precisely in the fact that they are not regarded as abnormal by the poet who even seems eager to adopt the supernatural logic of fairy tales or children's literature to describe the Welsh reality captured by Hurn. So much so that it eventually sounds perfectly natural that at some point "The fields have turned to cushions / And the hay has faces" (WP, p. 50); or that birds should be holding a meeting in Llanelli at the National Wetlands Centre:
At the Annual General Meeting of Waterbirds, plc,
It was declared that the Bay of Caernarfon had been overfished.
The Treasurer, defensive as only a Bridled Guillemot could be,
Said: "I am very sorry. Things are not as I would have wished.
But there is nothing to be done, and no dividend declared.
However, I assure the meeting that it's nothing I can't handle." (WP, p. 100)

Freud claims that the supernaturalism of the fairy tale does not inspire a sense of the uncanny because there is no conflict of judgement, no clash of different models of the real in it. The same, he argues, is true of the supernatural in Dante, Homer or Shakespeare:

The imaginative writer may have invented a world that, while less fantastic than that of the fairy tale, differs from the real world in that it involves supernatural entities such as demons or spirits of the dead. Within the limits set by the presuppositions of this literary reality, such figures forfeit any uncanny quality that might otherwise attach to them. The souls in Dante's Inferno or the ghostly apparitions in Shakespeare's Hamlet, Macbeth or Julius Caesar may be dark and terrifying, but at the bottom they are no more uncanny than, say, the serene world of Homer's gods. We adapt our judgment to the conditions of the writer's fictional reality and treat souls, spirits and ghosts as if they were fully entitled to exist, just as we are in our material reality. Here too there is no place for the uncanny. (Freud, 2003, p. 156)

21 However, Writing the Picture is not a fairy tale, and nor is it a children's book. Besides, Hurn never resorts to photomontage, and he photographs real settings. As a consequence, the discrepancy between what viewers or readers expect and the works they are offered does create uncanny effects. Hurn produces images that do not pander to audience expectations; and Fuller is more than willing to venture down this track. In this respect, the photos and poems in Writing the Picture have reached what Billy Jay calls a "Threshold-The Disturbing Image":

The image disturbs in the sense that it rocks the status quo and tends to break up the settled order of things. [...] Photographers, like all other specialists, cherish the traditions of their field of expertise. New departures create cracks in the shell and signal a period of vulnerability and anxiety. [...] The point is this: all the innovative image-makers have this tendency to rock the boat in which we feel so comfortable, huddled together with our peers. (Jay, 1995, pp. 33-42)

In fact, the photo of the meeting room in Llanelli (WP, p. 101) soon turns out to be troubling because the place is deserted (whereas one might have expected a true meeting with staff members); but also because the mural background of birds reflecting itself on the desks becomes almost three dimensional, the paper décor overwhelming 
men's world in general confusion: “The Chairman, a Black-Tailed Godwit, declared the meeting closed, / And in the general confusion no dividend was declared" (WP, p. 100).

Similarly, another photo shows a portrait of Dylan Thomas isolated in an extremely clean, almost aseptic environment (WP, p. 31). The café is empty, and the frameless picture of the poet almost vanishes in the geometric pattern of the wall paper; and once again human life seems to be absorbed by the material context. Instead of a lingering presence that would be celebrated on the occasion of a poetry reading with a crowd of admirers, Fuller's verse emphasizes the absence of a major poet whose chaotic life contrasts with the neatness of the coffee shop in Laugharne. The looming spectre of death therefore becomes all too invasive:

Missing: one poet in an ill-fitting suit and a smile

Who walked out one morning into his damaged life

And never returned for tea. (WP, p. 30)

\section{Uncanny plots}

\section{“Quietly, now. Pretend you don't see."}

Quite naturally, Hurn's distressing and anxiety-provoking images spawn uncanny plots in Fuller's verse. In the second part of his essay on the Uncanny, Freud dwells on the impressions apparently animate objects make on us, and he starts off quoting Jentsch:

"One of the surest devices for producing slightly uncanny effects through storytelling is to leave the reader wondering whether a particular figure is a real person or an automaton, and to do so in such a way that his attention is not focused directly on the uncertainty." (Quoted in Freud, 2003, p. 135)

This is particularly true of a photo showing male shoppers waiting in front of the window of a clothes store in Cardiff during Christmas 2004 (WP, p. 21). The shop window is a topos in the history of photography, and Hurn's is both humorous and eerie because the world of plastic mannequins seems to overbear the characters. The poem adds another uncanny dimension to the picture by voicing out the thoughts of the man on the left, who is now nothing but a photographic reproduction of the actual passer-by, a photographic object-hence the weird ventriloquism effects:

Don't look now, but we're outnumbered.

Somebody tugged those patchy jeans

Clean over the coy plastic nub of the groin,

Joined hand to jointed arm as if to say:

"Hey! You! What's on your mind? Just you try it!"

Quietly, now. Pretend you don't see. (WP, p. 20)

26 A tension arises from a latent competition between the mannequins and the men whose virility and strength is challenged by the perfect shapes of the plastic figures. The living are, disturbingly enough, in a position of inferiority, appearing lower than the mannequins safely protected behind the window.

In other pictures, the living themselves are comparable to mannequins, as though they were inanimate-or already dead-, as is evidenced by the young drug addict shooting up in the toilet (Brynmill, 1972, in WP, p. 67). No matter how much the girl may look like a model-she is Marilyn Monroe-like indeed-, the spotlight and high-angle shot tend to change her into a shadow of herself similar to a wax reproduction about to be swallowed into the pitch-black background. This photo is "both a pseudo-presence and 
a token of absence" in the literal sense of Susan Sontag's statement (Sontag, 2008, p. 16). It actually almost represents a living dead whose interior monologue stages a terrifying splitting of personality ensuing from heroin addiction, epitomized by the striking paradox of the final couplet of Fuller's sonnet:

I came here for some privacy, not out of fear.

Don't any of you look at me. I am not here. (WP, p. 66)

The antinomy ("I came here" / "I am not here") adds to the sense of impending doom while wiping out the limits between life and death, reality and fiction. This monologue may even sound like a prosopopoeia expressing the thoughts of a deceased character from beyond the grave. The real character in front of the camera has been entirely depersonalized, stripped of her identity, both by drug and by photography, "[she is] not here":

Linked to anguish, the uncanny strangeness does not, however, merge with it. Initially it is a shock, something unusual, astonishment; and even if anguish comes close, uncanniness maintains that share of unease that leads the self, beyond anguish, toward depersonalization. "The sense of strangeness belongs in the same category as depersonalization," Freud noted. (Kristeva, 1991, p. 188)

Yet, once robbed of their personality, the characters caught by the camera-eye nonetheless remain haunting presences. In consonance with Susan Sontag, Diane Arbus says that photographs "are the proof that something was there and no longer is. Like a stain. And the stillness of them is boggling. You can turn away but when you come back they'll still be there looking at you" (2003, p. 226).

\section{Striptease}

In a number of photos in Writing the Picture, not only do the characters look embarrassed, but the scenes themselves also make the viewers very uncomfortable-as though they were forced into voyeurism, forced to open up their eyes to a reality they do not want to see, coerced to probe the uncanny about themselves. Let us now focus on "Hen Night" taken in Usk in 1994 (WP, p. 45). The strength of this picture lies in a precarious balance between a festive mood and a sense of overrated hilarity, contrived joy, coupled with ambient malaise perfectly rendered by the opening stanzas of Fuller's poem:

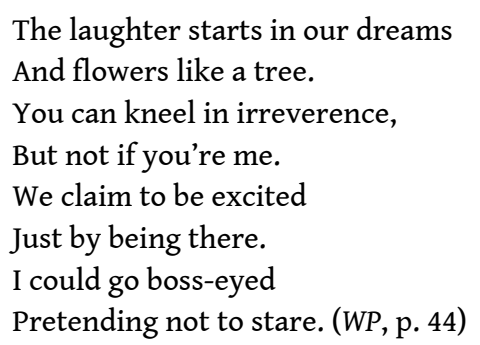

The laughter and applause sound overly loud, as if to hide embarrassment-not to mention disgust. Some of the women are even averting their eyes while others look obliquely, just like the viewers, both drawn to this perfect body and somehow intrigued, or repelled by blunt nakedness.

One may contend that the uncanniness about this scene is to be connected to a diseroticizing dynamic, which is all too disconcerting in this context. Indeed, the stripper is doing his job so thoroughly that it almost leaves no room for desire and fantasy, as is testified by Fuller's neutral detailed description: 
That little gymnast swings

To and fro on its bar

Or completes a circuit.

It's an utter star! (WP, p. 44)

In this stanza, Fuller alludes to both the stripper and his penis as diligent performers. "It" (contrary to "He") points out the objectification of the stripper turned into an automaton while also obviously referring to the male organ. But the sexual innuendo fails to express either lewdness or bawdiness. The Chippendale dancer is just completing his routine very professionally; and this is enhanced by the perfect regularity of the rhythm, notably the iambic sequence in "That little gymnast swings". Roland Barthes's remarks about striptease, whether the stripper be male or female, could perfectly apply to this scene:

Striptease is based on a contradiction: Woman is desexualized at the very moment when she is stripped naked. We may therefore say that we are dealing in a sense with a spectacle based on fear, or rather on the pretence of fear, as if eroticism here went no further than a sort of delicious terror, whose ritual signs have only to be announced to evoke at once the idea of sex and its conjuration. $(2009$, p. 97)

But then, after the conjuration of sex, Fuller's poem raises a very unsettling question:

When will the shrieks of laughter

Turn to disgust in the dark,

The little boy at bath-time

Become the threat in the park? (WP, p. 44)

Where does "The little boy at bath-time" come from? This sudden apparition is quite outlandish. Such a change in the tone of the poem is all the more forceful since it gets us to reconsider the picture: what is the link between the "little gymnast" and the "little boy"?

Because there is foam on the stripper's thighs and buttocks, one may think that the poet visualizes him when he was a little boy; or, possibly, the bride-to-be's future baby boy. But why should this boy become a "threat in the park"-i.e. an exhibitionist, a potential rapist? The invasion of doubles of the central character is both puzzling and scaring, in keeping with Freud's own remarks on the motif of the double:

The motif of the double has been treated in detail in a study by O. Rank. This work explores the connections that link the double with mirror-images, shadows, guardian spirits, the doctrine of the soul and the fear of death. It also throws a good deal of light on the surprising evolution of the motif itself. The double was originally an insurance against the extinction of the self or, as Rank puts it, 'an energetic denial of the power of death', and it seems likely that the 'immortal' soul was the first double of the body. The invention of such doubling as a defense against annihilation has a counterpart in the language of dreams, which is fond of expressing the idea of castration by duplicating or multiplying the genital symbol. [...] But these ideas arose on the soil of boundless self-love, the primordial narcissism that dominates the mental life of both the child and primitive man, and when this phase is surmounted, the meaning of the 'double' changes: having once been an assurance of immortality, it becomes the uncanny harbinger of death. (2003, p. 142)

Hurn's photo may first be viewed as "an energetic denial of the power of death" insofar as it will remain in time as a token of the stripper's vitality and beauty-an artistic double of his. Moreover, the vision of "The little boy at bath-time" goes counter to the unfolding of time by announcing renewal and regeneration. And yet, "this phase is [soon] surmounted" in Fuller's lines: "the meaning of 'double' changes" as soon as it becomes a dark shadow of the protagonist associated to crime ("the threat in the 
park"). Because the speaking "I" is deliberately ambiguous in the poem-being related by turns to the stripper, one of the women in the room, an omniscient speaker or even us, viewers and readers-, one may interpret the introduction of this menace as a projection of self-contained danger out of the self. "The Other Is My (Own and Proper) Unconscious", says Kristeva, before developing further:

Freud noted that the archaic, narcissistic self, not yet demarcated by the outside world, projects out of itself what it experiences as dangerous or unpleasant in itself, making of it an alien double, uncanny and demoniacal. In this instance the strange appears as a defense put up by a distraught self: it protects itself by substituting for the image of a benevolent double, that used to be enough to shelter it, the image of a malevolent double into which it expels the share of destruction it cannot contain. (1991, pp. 183-4)

Should the apparition of "the threat" in Fuller's poem be considered as a "defense", a verbal shield allowing the speaker to expel a share of destruction that cannot be contained?

Then, without any transition after this unforeseen experience, Fuller brings us back to a more reassuring frame corresponding to the ekphrasis proper: "My hand raised to applaud/ Touches my cheek in wonder" (WP, p.44). The readers are thus left flabbergasted, and on their own to deal with the uncanniness of the poem. The opening line of the conclusive stanza even seems to act as a foil to our own position in front of such artwork: "What does it say about me?" (WP, p. 44) As a matter of fact, any uncanny encounter is bound to question our own certainties:

Also strange is the experience of the abyss separating me from the other who shocks me-I do not even perceive him, perhaps he crushes me because I negate him. Confronting the foreigner whom I reject and with whom at the same time I identify, I lose my boundaries. [...] I feel "lost," "indistinct," "hazy." The uncanny strangeness allows for many variations: they all repeat the difficulty I have in situating myself with respect to the other. (Kristeva, 1991, p. 187)

Ironically enough, in the last three lines the menace now comes from the women themselves, testifying to the male character's "difficulty in situating [himself] with respect to the [female] other" that may get too close... and threaten his manly limbs:

I'm not quite happy yet.

What do they know that I don't?

How close can they get? (WP, p. 44)

\section{"Where is Happy Lion? Mr Toad?"}

It is important to remember that Freud traces the uncanny back to infantile terrors and desires. When analyzing Hoffmann's "Sandman", he notes that the sense of the uncanny attaches directly to the main character's fear of being robbed of his limbs, more precisely his eyes (see Freud, 2003, p. 138). Such childhood dread underpins Writing the Picture and characterizes more specifically a sonnet inspired by the picture of the refuse transfer site of Penpac taken in 1999 (WP, p. 71). Surprisingly, we can see a large collection of discarded teddy bears hanging along the fence of a dump. Hurn's personal recollected reaction to this sight is quite telling:

You are driving along, minding your own business, looking at the pretty trees. Then you come round the corner and suddenly you see something like this. It was what you would call a rubbish tip, near Cardigan in west Wales, although I later discovered that it was actually called a "refuse transfer site". The guy who ran it obviously had some interest in the arts, and he discovered early on that there were 
a lot of discarded toys in the rubbish, so he gradually started taking them out and hanging them on the fence. My first impression on coming across it was just: "Isn't life wonderful?" [...]

After talking to the guy who had done it, I walked along the fence with my $35 \mathrm{~mm}$ Leica, and probably a $35 \mathrm{~mm}$ lens, trying to find the most unusual grouping of toys. Then it was a matter of trying to get the right position. My guess is that the fence was about three times as long as you can see in the picture. But the problem with being a long way away from it, in order to see it all, is that you would have a lot of sky and a lot of foreground. So I tried to get close enough to fill the frame, but far enough away to get as many toys in as possible, and give the feeling that there were a lot of them. Really, it was a case of trying to make every little corner of the frame important.

The idea of another human being thinking that it's worth his while to go through the rubbish on his tip and pull out the little dolls and put them on a fence-it's miraculous. I'm still startled that people have the inventiveness to do something like that. It makes me have a little more faith in human beings. ${ }^{7}$

\section{with a quest involving the reader:}

Where is Happy Lion? Mr Toad?

Where is drunk dolly of the knitted legs? (WP, p. 70)

The choice of a series of questions is all the shrewder because it implies various levels of reading. As in children's poetry, riddles invite readers to go back and forth across the picture in order to find each toy mentioned in the text, thereby prolonging the wonder that had enthralled Hurn. Yet, as Auden famously claimed, "poetry is not magic. In so far as poetry, or any other of the arts, can be said to have an ulterior purpose, it is, by telling the truth, to disenchant and disintoxicate" $(1989$, p. 27). Given the context of the picture, we may soon understand that Fuller's verse is no nursery rhyme. The teddy bears are nowhere to be found except in a dump, as we are inexorably reminded in the conclusive line changing the scene into an eerie contemporary Welsh Vanitas: "And the winds are blowing rubbish down the hill".

In addition, the forsaken dolls relate to all children's fear of losing their cherished cuddly toys which are like an extension of themselves. They consequently also embody the terror of amputation: "Threadbare, stitched-up, hang-dog, button-blind" (WP, p. 70). On the other hand, their fate may express a primitive anxiety already experienced by each and every one of us as early as infancy, namely, the fear of abandonment:

Banished for ever, or else left behind,

And no one comes for them, nor ever will. (WP, p. 70)

"As for solitude, silence and darkness, all we can say is that these are factors connected with infantile anxiety, something that most of us never wholly overcome" (Freud, 2003, p. 159). However, in both Hurn's and Fuller's works, aren't the discarded toys once again reunited in a family of sorts? Aren't the worn out ordinary objects also uncannily elevated to the status of art and revered by artists who consider their apparition "miraculous", in line with Hurn's own approach to beauty?

The photographer's aim is to create beautiful pictures, of any and all subject matter. [...] For many people the word beauty is associated with the predictablepictures previously seen and already in their memory banks [...]. For me, most great photographs displaying beauty reveal a sensation of strangeness, not predictability, a kind of shock non-recognition inside the familiar. (Hurn \& Jay, 2009, p. 70) 


\section{Conclusion: "A smile, seraphic, / And one long- stemmed rose"}

41 Though their works might seem unrelated in many respects, one can sense that, like Diane Arbus, David Hurn is prone to marveling at the beauty and wonders of small things. And this quote by Arbus dating from November 1939 could serve as a caption to more than one photo in Writing the Picture:

Everything that has been on earth has been different from any other thing. That is what I love: the differentness, the uniqueness of all things and the importance of life... I see something that seems wonderful; I see the divineness in ordinary things. (2003, p. 70)

Hurn has a knack for capturing the sacredness of daily life, be it the descent of seagulls fed by an old woman on a pier ("Sixty years from our wonder we expect a miraculous descent", WP, p.16); a primitive outdoor sculpture made by a farmer out of cement, broken crockery and the head of an old baby doll ("But to greet you at the farm / Is this still Sibyl, answering / Everything and nothing”, WP, p. 15); or an ordinary middle-aged woman about to cross a street in Cardiff with a rose in her left hand:

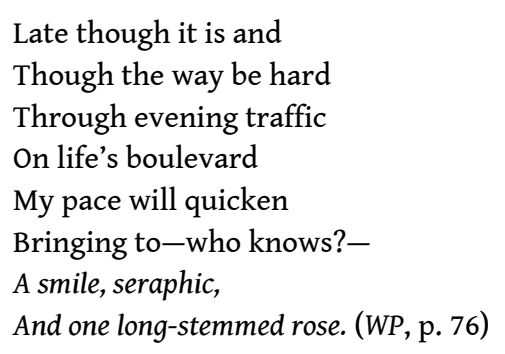

Although there is no religious dimension about Writing the Picture, the photos and poems testify to a quest for-or a return of-the sacred as it is defined by the French philosopher Jean-Claude Pinson:

Quelque chose, phénoménologiquement, prend l'allure du sacré lorsqu'il est appréhendé comme mysterium tremendum et fascinans, comme ce que Rudolf Otto appelle le " numineux ». En tant que mystère, il se donne en se voilant, en se réservant, à la manière du secret de l'Etre heideggerien. D'autre part, il est appréhendé à travers une tonalité affective (Stimmung) ambivalente : il y a en même temps saisissement, effroi, mouvement de recul et attirance, "sentiment de la merveille", pour reprendre une expression de Julien Gracq. $\left(1995\right.$, p. 113) ${ }^{8}$

What singularizes Writing the Picture, though, is that the advent of the sacred is almost always preceded by a stage of uncanniness. Hurn and Fuller are surely more fascinated by what the photographer calls "miraculous" sights than in awe, but there is no denying that their art emanates from a mysterium tremendum et fascinans witnessed in ordinary life. This is epitomized by the curious procession of wild goats seized by Hurn in Llanaelhaearn in 2008 (WP, p. 93), and by the unpredictable imagery in Fuller's verse:

Dignitary, chieftain, concubine,

They shift the clattering scree in stately line

Like someone's weariness in washing up

Cup after cup after cup after cup after cup.

Then turn the mountain-top into a shrine. (WP, p. 92)

Startlingly enough, the ascent of those dignified goats coming out of the blue on the edge of a deserted, almost ruined cliff is compared to the domestic task of washing up the dishes. However much the odd compulsive repetition ("Cup after cup...") may be 
interpreted as an attempt to render the slowness of the scene as well as its acoustics (the sounds of crockery in the sink echo like the clattering steps of the goats on the schist ground), it fails to anticipate the final sacred vision. This leaves the readers speechless... and beguiled by the restored order of a "mountain-top [turned] into a shrine". The camera has this power to pinpoint the extra-ordinary ("unheimlich") held within the ordinary ("heimlich"), while sometimes glimpsing sacredness on the horizon of our daily life. Altogether, aren't some photos comparable to sealed receptacles of the light of creation-tremendum et fascinans?

The earliest photographs of Vega captured

Light sent before photography's invention.

Out of the dark we come. Into the dark we go.

Your shutter greedily gulps its share of light,

And the distinctive absences of light. (Fuller, 2015, p. 74)

\section{BIBLIOGRAPHY}

ARBUS Diane, 2003, Revelations, London, Random House.

Auden Wystan Hugh, 1989, The Dyer's Hand [1962], New York, Vintage Books.

Auden Wystan Hugh, 1994, Collected Poems [1976], London, Faber.

BARTHES Roland, 2009, Mythologies [1957], translated by Annette Lavers, London, Vintage.

FREUD Sigmund, 2003, The Uncanny [1919], translated by David McLintock, London, Penguin Books.

FUlLER John, 1998, W. H. Auden: A Commentary, Princeton, Princeton University Press.

FULLER John, 2012, New Selected Poems 1983-2008, London, Chatto \& Windus.

FULLER John, 2014, You're Having Me On, Holt, Wiltshire, Laurel Books.

FULLER John, 2015, Gravel in My Shoe, London, Chatto \& Windus.

FULLER John \& HURN David, 2010, Writing the Picture, Bridgend, Wales, Seren.

HURN David \& JAY Bill, 2000, On Looking at Photographs, Portland, LensWork Publishing.

HURN David \& JAY Bill, 2009, On Being a Photographer, Anacortes, LensWork Publishing.

JAY Bill, 1995, Occam's Razor: An Outside-In View of Contemporary Photography, Tucson, Nazraeli

Press.

KRISTEVA Julia, 1991, Strangers to Ourselves [1988], translated by Leon S. Roudiez, Hemel

Hempstead, Harvester Wheatsheaf.

PINSON Jean-Claude, 1995, Habiter en poète, Seyssel, Champ Vallon.

SoNTAG Susan, 2008, On Photography [1977], London, Penguin Modern Classics. 


\section{NOTES}

1. In all the quotes, the italics are mine.

2. Henceforth, we shall use WP as an abbreviation of Writing the Picture (Fuller \& Hurn, 2010).

3. Almost all the photos under study in this article can be found on the following website: <https://pro.magnumphotos.com/C.aspx?VP3=SearchResult\&ALID=2K1HRGWPJX3Q>.

4. In Welsh language poetry, the cynghanedd (literally "harmony") is a form based on soundarrangement within one line, using stress, alliteration and rhyme. Here, Fuller chose a specific form of cynghanedd whereby at least three consonants in the first half of the line are repeated in the same order in the second half.

5. John Fuller wrote a major work on W. H. Auden whom he regards as one of his mentors (see Fuller, 1998).

6. See, for example, Mr and Mrs Robert Andrews (1748-1750) by Thomas Gainsborough.

7. <www.theguardian.com/arts/graphic/0,2275762,00.html>.

8. In phenomenology, things start bearing sacred overtones when they are approached as mysterium tremendum et fascinans-i.e. as what Rudolf Otto calls the "Numinous". As mysteries, they reveal themselves to us through a veil, reservedly, not unlike the secret of Heidegger's Being. Moreover, they are approached through an ambivalent affective tone (Stimmung), simultaneously engendering shock and dread, attraction and recoil-what Julien Gracq calls the "feeling of wonder". (My translation)

\section{ABSTRACTS}

From the late 1980s onwards, John Fuller started writing poems intended to illustrate several pictures taken by David Hurn between 1966 and 2009. This collaboration-which is unprecedented in the history of Welsh art-gave rise to the publication of Writing the Picture in 2010. At the confluence of two aesthetics that keep on feeding each other, this collection of duotone images and poems is undeniably imbued with a sense of what Freud calls "the Uncanny". Indeed, according to Hurn, who also is a photography theoretician, the best pictures produce forms of strangeness that are crucial to their success. And the uncanniness characterizing his art -including the weirdness of ordinary scenes of the Welsh daily life-obviously fascinated Fuller whose perfect mastery of complex forms always testifies to some unfulfilled wish to better grasp the mysteries of the real.

À partir de la fin des années 1980, John Fuller commence à illustrer de ses vers plusieurs photos de David Hurn prises entre 1966 et 2009. Le fruit de cette collaboration inédite dans l'histoire de l'art gallois donnera lieu à l'ouvrage Writing the Picture publié en 2010. Ce recueil, au confluent de deux esthétiques qui n'ont de cesse de s'enrichir mutuellement, est sans conteste baigné d'une " inquiétante étrangeté » au sens de Freud. Pour le théoricien qu'est Hurn, c'est en effet de son caractère étrange que toute grande photo tire sa force. Et c'est sans nul doute cette caractéristique de ses plus grands clichés - et l'étrangeté de scènes ordinaires du quotidien qui fascine Fuller, dont la parfaite maîtrise des formes poétiques les plus complexes témoigne toujours en creux d'un désir à jamais inassouvi de mieux cerner les mystères du réel. 


\section{INDEX}

Mots-clés: Fuller, Hurn, poésie, photographie, inquiétante étrangeté

Keywords: Fuller, Hurn, poetry, photography, uncanny

\section{AUTHOR}

\section{AURÉLIEN SABY}

Aurélien Saby earned a PhD in 20th century poetry from Paris-Sorbonne University (Paris 4) in 2013. His dissertation bore on the city in W. H. Auden's work. His research currently focuses on both W. H. Auden and the post-Auden generation. He wrote several articles on Auden, on the contemporary poet John Fuller and on the Welsh photographer David Hurn. He teaches at lycée Hélène Boucher (CPGE) in Paris. He has published articles on entitled “'Don't look at me, don't look' I'm doing wrong... to myself! A Poetic Approach to Drug Addiction by John Fuller and David Hurn" (in Wrongdoing, actes du colloque international Wrongdoing, Realities, Representations, Reactions, 23-25 juin 2015; textes réunis par Elizabeth Durot-Boucé), “W. H. Auden and the Mezzogiorno" in Literature and Geography, The Writing of Space throughout History, edited by Emmanuelle Peraldo (Cambridge Scholars Publishing, 2016), and “Lecture de 'Down There' de W. H. Auden : de la cave des origines au retour de la guerre" in the online journal Polysèmes. 